\title{
Study on the Effectiveness of Infiltration Wells to Reduce Excess Surface Run Off In ITB
}

\author{
Afifah Muhsinatu Mardiah, ${ }^{1, *}$, Cherish Nurul Ainy ${ }^{2}$, Mohammad Bagus $^{3}$, and Dhemi Harlan ${ }^{3}$ \\ 1 Study Program of Civil Engineering, Faculty of Civil and Environmental Engineering Institut Teknologi Bandung, Jln. \\ Ganesha No. 10 Bandung, Indonesia \\ ${ }^{2}$ Master Program of Landscape Architecture, School of Design, Planning and Development Policy Institut Teknologi Bandung, \\ Jln. Ganesha No. 10 Bandung, Indonesia \\ ${ }^{3}$ Water Resources Engineering Research Group, Faculty of Civil and Environmental Engineering Institut Teknologi Bandung, \\ Jln. Ganesha No. 10 Bandung, Indonesia
}

\begin{abstract}
Institut Teknologi Bandung (ITB), Ganesha Campus, Indonesia, has an area of 28.86 hectares. The campus is located in Bandung. Starting from 2012, new buildings were constructed within the area, reducing the area of permeable surface significantly. In the past few years, there were several excess run off incidents in the campus. The insufficient area of permeable surface as well as the inadequate capacity of the drainage system contributes to the excess surface run off. The drainage system has only two outlets. Moreover, in some areas, the drainage systems are disconnected. Thus, most the surface run off are stored within the drainage system. The purpose of this study is to evaluate the effectiveness of infiltration wells for reducing the local excess run off in ITB. Precipitation data and drained service area are used to estimate the design discharge from each building in ITB. In order to avoid the excess surface run off of certain locations in ITB, then the infiltration wells are proposed to balance the area of impermeable surface. The effectiveness of the infiltration wells are evaluated by assessing their number to their contribution in reducing the excess surface runs off.
\end{abstract}

\section{Introduction}

Precipitation in Bandung area has increased in the past few years. The rainfall intensity in the last 25 years ascends by $10-20 \mathrm{~mm}$ every year [1].Based on Regional Regulation No. 26 of 2007 on Green Area (Ruang

Terbuka Hijau/RTH), - from 661.4 thousands hectare area of Citarum River Basin, 198 thousands is supposed to be reserved area. In accordance with Regional Regulation No. 2 of 2016 on controlling the utilization of North Bandung Area (Kawasan Bandung Utara/KBU), the local government - tries to protect KBU by limiting physical development to only $20 \%$ of land area. Area of KBU Bandung is 38 thousands, but $80 \%$ have been intervened by constructions. The increase in industrial activities eventually increases the degree of groundwater withdrawal from the aquifers in Bandung [2]. Thus, most the surface run off are stored within the drainage system. Furthermore, land use and land cover change affect hydrological components such as interception, infiltration and evaporation. They influence the soil moisture content, runoff generation (both process and volume) and stream flow regimes [3]. Previous surfaces decrease the amount of runoff as precipitation infiltrates [4]. These also affect the groundwater table [5].

As well as the city of Bandung, new buildings have been constructed within the area of ITB. These building significantly reduce the permeable area. Soil type in the area is mostly clay up to 6 meters depth, which has a slow infiltration rate. The construction was not followed by increasing the capacity of the drainage system. Thus, excess runoff occurs quite frequently during the last few years in a few internodes such as Labtek V,VI,VII,VIII, Aula Timur and Lapangan Seni Rupa.

One of the solutions to reduce excess surface run off is infiltration wells. Infiltration wells are structures that highly allow surface runoff to drain through underground [6]. Infiltration well was initiated in Indonesia by Sunjoto [7] and developed by some other researchers [6,8-10]. The benefits of infiltration wells are a quantity of unconfined groundwater can be conserved, the surface level of unconfined ground water stays stable, the area of ponding water is minimized, and the dimension of drainage networks is minimized. In addition, the groundwater quality is improved, land subsidence is prevented, and salt water intrusion in coastal area is avoided [11]. The disadvantage of infiltration wells is the infiltration takes time depending on the permeability. The purpose of this study is to evaluate the affectivity of infiltration wells in order to reduce the excess surface run off in ITB.

\section{Methodology}

The results in this paper are based on two wellestablished and complementary hydrology analysis and infiltration wells standard design. They are SNI T-02-022006 for Local Drainage Design and SNI 03-2453-2002 for Infiltration Wells Design. The design is based on the available topography, hydrology, and soil data. The hydrology data are as follows:

1. Precipitation of Metropolitan Bandung Raya Data (2017-2015)

\footnotetext{
* Corresponding author: mardiahafifah@gmail.com
} 
2. Precipitation of ITB station (AWS November 2011-December 2016)

3. Drainage system map

\subsection{Hydrology}

Hydrology analysis was conducted based on the daily maximum precipitation. The maximum precipitation in a return period can be estimated through 4 distribution methods such as normal, log normal, log pearson III and gumbel ${ }^{12}$. The methods concepts are fitted to probability concepts. SNI T-02-02-2006 states that the local drainage system design is based on a 5 years return period.

\subsection{Standard Design for Infiltration Wells}

SNI 03-2453-2002 states the general requirements of infiltration wells are as follows:

1. Infiltration wells are placed relatively in flat contour;

2. The water entering the catchment is unpolluted rainwater;

3. Decision of infiltration wells shall take into safety building;

4. It must pay attention to local regulations;

5. Things that do not meet these requirements shall be approved by authorized agencies.

Technical requirements that must be included are in the following:

1. To ground water minimum 1.5 meter in the rainy season;

2. The usable soil structure should have soil permeability $\geq 2.0 \mathrm{~cm} /$ hour.

The shape and type of the infiltration well can be either an infiltration wells made in quadrilateral or cylindrical with a certain depth and the bottom of the well is located above the groundwater level. Based on the Regional Disaster Management Agency of Jakarta, types of infiltration wells construction are:

1. Wells without couple walls, bottom without filled stone or fibers (empty).

2. Wells without couple walls, bottom filled with stones and fibers

3. Wells with brick, stone or stone compartments on the wells wall, bottom filled with stones and fibers or empty

4. Wells use blawong (rock formed specifically for wells wall).

\section{Results and Discussions}

\subsection{Topography and Impermeable Surface}

Topography map data with a $50 \mathrm{~cm}$ contour interval is provided to continue the study. ITB has a relatively mild slope, almost flat, with the north is higher than the south.

The map of constructed area in ITB is also given to by Infrastructure Facilities Division of ITB. Most of areas in ITB are impermeable surface, such as building, pavement area (parking, plaza, and corridor) and roadway thus ITB has more impermeable surface. The total building area in ITB is $99,733 \mathrm{~m}^{2}$. Open space are garden, median, and island. ITB has less of infiltration area and the excess surface run off would drastically increase at the time of heavy precipitation.

\subsection{Drainage Systems}

The existing drainage systems were analyzed based on the drainage network data as shown in figure 1 . In addition, field survey was conducted to assess the flow direction. In general, the condition of existing drainage in ITB: (1) The drainage systems are disconnected in some places, (2) The drainage system has 2 outlet points but the remaining functional outlet is Dago. Furthermore, the drainages in several points were clogged as shown in figure 1. In some places, the channels dimensions were relatively small and might be in insufficient during a heavy rain. Additionally, the flow directions in some sections were not heading to any outlet causing excess surface run off within the area.

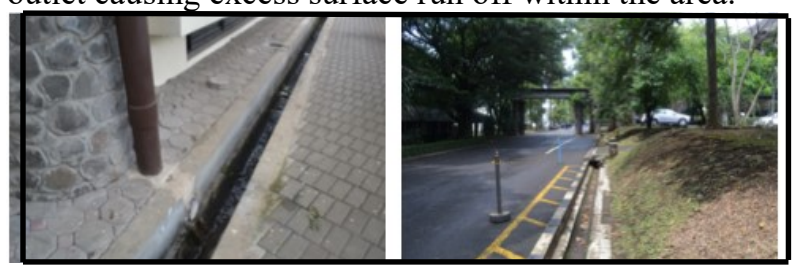

Fig. 1. Existing Drainage of ITB

\begin{tabular}{c|l} 
Depth & $0.00-1.5 \mathrm{~m}$ Silty Clay, dark brown, medium stiff, high plasticity \\
\hline $1.50-2.00$ & \\
$2.00-2.45$ & \\
$3.00-3.50$ & $2.45-3.00 \mathrm{~m}$ Silty Clay with some gravel, brown, medium stiff, high plasticity \\
& $3.50-4.00 \mathrm{~m}$ D.0 \\
$4.00-4.45$ & $4.45-5.00 \mathrm{~m}$ D.0 \\
\hline & $5.00-6.00 \mathrm{~m}$ Clayey Silt with some gravel, brown, spoted yellow, low plasticity \\
\hline $6.00-6.45$ & 6 \\
\hline $8.00-8.45$ & $6.45-8.00 \mathrm{~m}$ Sandy Gravel with some clay, brown, well graded, fine grained \\
\hline $10.00-10.45$ & $8.45-10.00 \mathrm{~m}$ Gravelly Sand, grey brown, well graded, coarse grained
\end{tabular}

\subsection{Soil Characteristics}

Fig. 2. Soil Characteristics in ITB

The characteristic of soil in ITB depend on the depth of the soil (Soil investigation FTTM Building, 2012). Between 0-1.5 meter depth is silty clay with dark brownish, medium stiff and high plasticity. This kind of soil takes time to infiltrate water [12]. The ground water table reached $>20 \mathrm{~m}$. The coefficients permeability of silty clay is $0.48\left(\mathrm{~m}^{3} / \mathrm{m}^{2} /\right.$ day $)$ or $1.3 \times 10-4 \mathrm{~m} / \mathrm{sec}$.

\subsection{Hydrology Analysis}

The data are ITB station and Dago Pakar Station in $06^{\circ}$ 52' 51" South Latitude and 107036' 52"' East Longitude. Maximum daily precipitation design for the area is calculated using arithmetic mean method. The average maximum daily precipitation data of both stations are shown in the table 1 . 
Table 1. Maximum Daily Precipitation Design

\begin{tabular}{|l|l|}
\hline Year & Maximum Precipitation (mm) \\
\hline 2007 & 113 \\
\hline 2008 & 80 \\
\hline 2009 & 73 \\
\hline 2010 & 104 \\
\hline 2011 & 45 \\
\hline 2012 & 61.6 \\
\hline 2013 & 70.75 \\
\hline 2014 & 95.65 \\
\hline 2015 & 65.3 \\
\hline 2016 & 71.4 \\
\hline
\end{tabular}

The design precipitation was statistically analyzed using the Normal, Log Normal, Log Pearson III, and Gumbel methods. The area design is the area of ITB which is 28.865 ha. According to SNI T-02-2006, the design precipitation return periods are $5,10,15,20$ year. In this paper, the return period used is 5 years because the scope of the area is university. Based on the results, the smallest error is Log Normal Method with a 5 years return period daily precipitation of $98.15 \mathrm{~mm}$.

\subsection{Infiltration Wells Design}

\subsubsection{Infiltration Wells Capacity}

The design of infiltration wells has 1 meter diameter with the depth of 10 meter and infiltration efficiency is $100 \%$. Soil clay has coefficient permeability 0.48 $\mathrm{m} 3 / \mathrm{m} 2 /$ day and course sand has $0.864 \mathrm{~m}^{3} / \mathrm{m}^{2} /$ day.

\section{Surface run off volume $\left(\mathrm{V}_{\mathrm{AB}}\right)$}

For every $500 \mathrm{~m}^{2}$ of service area, the surface run off volume is given as.

$$
V_{\mathrm{AB}}=0.855 \times 0.75 \times 500 \times 98.15 \times 10^{-3}=31.47 \mathrm{~m}^{3}
$$

2. Storage volume after precipitation $\left(\mathrm{V}_{\mathrm{STO}}\right)$

The infiltration wells have 1 meter diameter and 10 meter depth along the vertical permeability $(\mathrm{Kv})$ is calculated as below:

$$
\begin{gathered}
K_{\mathrm{V}}=(0.48 \times 1.5+0.864 \times 4.95+8.64 \times 3.55) / 10 \\
K v=3.57 \mathrm{~m}^{3} / \mathrm{m}^{2} \mathrm{hr}
\end{gathered}
$$

The infiltration wells is not impermeable, thus the water could flow as an infiltration or percolation (flowing through 2 axes). The horizontal permeability $(\mathrm{Kh})$ is twice the vertical permeability, so the value is $7.13 \mathrm{~m}^{3} / \mathrm{m}^{2} /$ day.

The precipitation duration (Tc) is the time for the precipitation to prolong.

$$
\begin{gathered}
T c=0.9 \times R^{0.92} \\
T c=0.9 \times 98.15^{0.92}=1.02 \text { hours }
\end{gathered}
$$

The total permeability (Kaverage) of the infiltration wells for permeable walls is

$$
K_{\text {average }}=(K v \times A h+K h \times A v) /(A h+A v)
$$

Where Ah is area of base wells, Av is area of wall wells. For the 10 meter depth of wells,

$$
\begin{gathered}
A h=\Pi D^{2} / 4=\Pi 1^{2} / 4=0.785 \mathrm{~m}^{2} \\
A v=\Pi D H=\Pi \times 1 \times 10=31.4 \mathrm{~m}^{2}
\end{gathered}
$$

$\mathrm{D}$ is diameter of wells and $\mathrm{H}$ is height of wells

$$
\begin{gathered}
K_{\text {average }}=(3.57 \times 0.785+7.13 \times 31.4) /(0.785+31.4) \\
K_{\text {average }}=7.0468 \mathrm{~m}^{3} / \mathrm{m}^{2} / \text { day }
\end{gathered}
$$

Volume of infiltration water during the precipitation with $\mathrm{Tc}=1.02$ hours is

$$
\begin{gathered}
V_{r s p}=T c / 24 A_{\text {total }} \times K_{\text {average }} \times \text { efficiency } \\
V_{r s p}=1.02 / 24 \times(0.785+31.4) \times 7.0468 \times 100 \% \\
V_{r s p}=9.64 \mathrm{~m}^{3} \\
V_{S T O}=V_{A B}-V_{r s p}=31.47-9.64=21.82 \mathrm{~m}^{3}
\end{gathered}
$$

3. Infiltration Wells Total

The total of infiltration wells is depends on storage volume.

$$
H=V_{\text {STO }} / A h=21.82 / 0.7854=27.79 m
$$

For 10 meter depth of infiltration wells, with a service area of $500 \mathrm{~m} 2$, the number of infiltration wells needed is:

$$
\text { Total wells }=H / \text { Hdesign }=27.79 / 10 \approx 3 \text { wells }
$$

\subsubsection{Infiltration Wells Application for ITB}

If the totals of infiltration wells are designed according to roof area per building, with the total roof area 99,733 $\mathrm{m}^{2}$, ITB is supposed to have 770 wells with the total area of wells is $604.757 \mathrm{~m}^{2}$. The number of infiltration wells per building is given in table 2 . 
Table 2. Number of infiltration wells per building

\begin{tabular}{|c|c|c|c|c|}
\hline No & Building & $\operatorname{Area}\left(\mathrm{m}^{2}\right)$ & $\mathbf{n}_{1}$ & $\mathbf{n}_{2}$ \\
\hline 1 & Kriya & 153 & 0.4 & 1 \\
\hline 2 & STJR & 190 & 0.4 & 1 \\
\hline 3 & FSRD & 294 & 1.2 & 2 \\
\hline 4 & FTSL & 341 & 1.6 & 2 \\
\hline 5 & PPFK & 409 & 2.4 & 3 \\
\hline 6 & LAB RADAR & 452 & 2.8 & 3 \\
\hline 7 & KANTIN BENGKOK & 460 & 2.8 & 3 \\
\hline 8 & PSDA II & 583 & 3.6 & 4 \\
\hline 9 & PSDA I & 611 & 4.0 & 4 \\
\hline 10 & KIMIA BARU & 741 & 4.8 & 5 \\
\hline 11 & DOPPING & 794 & 5.2 & 6 \\
\hline 12 & BANKER & 807 & 5.6 & 6 \\
\hline 13 & BSC B & 847 & 5.6 & 6 \\
\hline 14 & OKTAGON & 1036 & 7.2 & 8 \\
\hline 15 & TVST & 1036 & 7.2 & 8 \\
\hline 16 & BSCA A & 1066 & 7.6 & 8 \\
\hline 17 & LAB PLN & 1098 & 7.6 & 8 \\
\hline 18 & GKU TIMUR & 1116 & 8.0 & 8 \\
\hline 19 & CC TIMUR & 1177 & 8.4 & 9 \\
\hline 20 & COMLAB TPB & 1157 & 8.4 & 9 \\
\hline 21 & KONVERSI & 1291 & 9.2 & 10 \\
\hline 22 & PPTI & 1394 & 10.0 & 10 \\
\hline 23 & CADL & 1634 & 12.0 & 12 \\
\hline 24 & KIMIA LAMA & 1647 & 12.0 & 12 \\
\hline 25 & GKU BARAT & 1675 & 12.4 & 13 \\
\hline 26 & CC BARAT & 1776 & 13.2 & 14 \\
\hline 27 & AULA BARAT & 1879 & 14.0 & 14 \\
\hline 28 & RME & 1888 & 14.0 & 14 \\
\hline 29 & LAB HIDRAULIKA & 1993 & 14.8 & 15 \\
\hline 30 & CRCS & 2028 & 15.2 & 16 \\
\hline 31 & LABTEK CIII & 2134 & 16.0 & 17 \\
\hline 32 & CAS & 2172 & 16.4 & 17 \\
\hline 33 & SBM & 2312 & 17.6 & 18 \\
\hline 34 & PERPUS PUSAT & 2428 & 18.4 & 19 \\
\hline 35 & T.LING & 2496 & 18.8 & 19 \\
\hline 36 & LABTEK VI & 2732 & 20.8 & 21 \\
\hline 37 & PAU & 2736 & 20.8 & 21 \\
\hline 38 & LABTEK II & 2930 & 22.4 & 23 \\
\hline 39 & LABTEK VIII & 2982 & 22.8 & 23 \\
\hline 40 & LABTEK I & 2995 & 22.8 & 23 \\
\hline 41 & LABTEK VII & 3088 & 23.6 & 24 \\
\hline
\end{tabular}

\begin{tabular}{|c|c|c|c|c|}
\hline No & Building & $\operatorname{Area}\left(\mathrm{m}^{2}\right)$ & $\mathbf{n}_{1}$ & $\mathbf{n}_{2}$ \\
\hline 42 & LABTEK V & 3158 & 24.4 & 25 \\
\hline 43 & LABTEK III & 3259 & 25.2 & 26 \\
\hline 44 & LABTEK VI & 3281 & 25.2 & 26 \\
\hline 45 & TEKNIK SIPIL & 3354 & 26.0 & 27 \\
\hline 46 & LAB MESIN & 3423 & 26.4 & 27 \\
\hline 47 & AULA TIMUR & 3572 & 27.6 & 28 \\
\hline 48 & CADL LAMA & 4076 & 31.6 & 32 \\
\hline 49 & LABTEK IX & 4147 & 32.0 & 33 \\
\hline 50 & FISIKA & 5265 & 41.2 & 42 \\
\hline 51 & LABTEK X\&XI & 5620 & 44.0 & 45 \\
\hline \multicolumn{2}{|c|}{ TOTAL } & 99733 & 745.5 & 770 \\
\hline \multicolumn{3}{|c|}{ TOTAL AREA OF WELLS $\left(\mathrm{m}^{2}\right)$} & 585.5 & 604.8 \\
\hline
\end{tabular}

Nb. $n_{1}$ is number of wells and $n_{2}$ is number of wells round up.

Infiltration wells are expected to reduce the amount of water that flow from the outlets to the roadside public drainage. This means that ITB run off contribution to the city drainage system will be reduced significantly.

Infiltration wells are prioritized in the area with known history of excess surface run off such as Aula Timur, Lapangan Seni Rupa and Aula Barat. The wells can either be an infiltration well, connected to the drainage system (drainage well), or not (RTH well). The locations are shown in figure 3 .

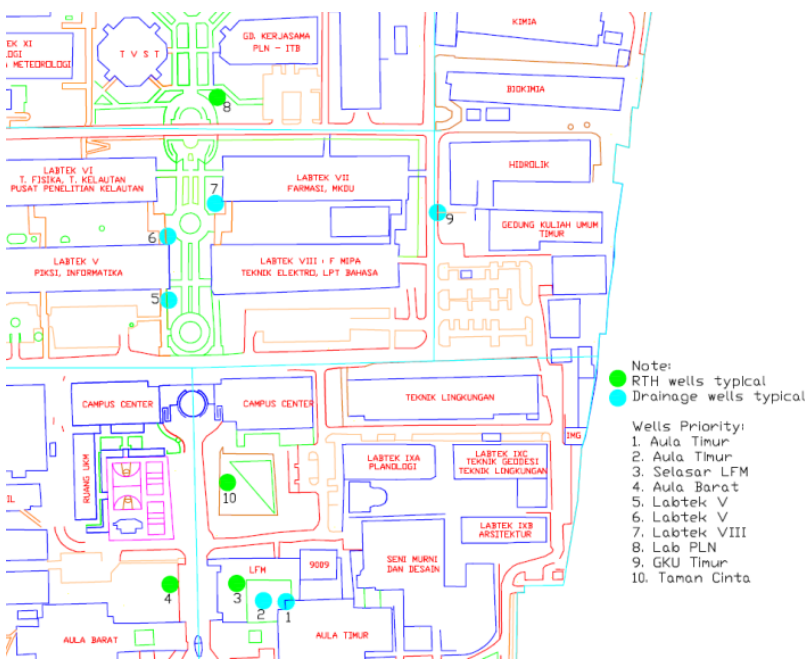

Fig. 3. Priority Wells of ITB

\section{Conclusions}

In this study, the effectiveness of infiltration wells to reduce the excess local run off in ITB has been assessed. The ground water table is located 20 meter depth and in general, the soil type is clay thus the infiltration wells may not be the best answer to the excess run off problem for ITB.

Dimension of the infiltration well is 1 meter diameter and 10 meter depth. It was found that for a service area of $500 \mathrm{~m}^{2}, 3$ wells are needed. Therefore, to retain $100 \%$ 
precipitation from the buildings into wells, ITB needs approximately 770 wells.

Due to the large number of wells needed, it is recommended to construct these wells only in several locations, at internodes that have high excess run off. In addition, it is recommended to develop a new master plaster plan for the ITB drainage system.

The authors would like to express their gratitude to the Infrastructure Facilities Division of ITB for providing the data.

\section{References}

1. A. Arif, Jangan Salahkan Cuaca Berubah, Kompas, https://www.pressreader.com/indonesia/kompas/201 70320/281857233354137, (17 June 2017)

2. I. Gumilar, et al, Land subsidence in Bandung Basin and its possible caused factors, Procedia Earth and Planetary Science, 12, 47-62 (2015)

3. W. Gumindoga, Hydrology Impact of Landuse Change in the Upper Gilgel Abay River Basin, Ethiopia, TOP MODEL Application, Integrated Watershed Management and Modelling (2010)

4. Haselbach, M. Liv, S. Valavala, F. Montes, Permeability predictions for sand-clogged Portland cement pervious concrete pavement systems, Journal of Environmental Management, 81, 42-49 (2006)

5. F. DeSmedt, O. Batelan, The impact of land use changes on the groundwater in the Grote Nete River Basin, Belgium, Conference Future of Groundwater Resources, 151-158 (2001)

6. Y. Arafat, Reduksi Beban Aliran Drainase Permukaan Menggunakan Sumur Resapan, SMARTek, 6, 144-153 (2008)

7. S. Sunjoto, Optimization of infiltration well to avoid salted water intrusion in coast areas, IUC-UGM, Yogyakarta (1988)

8. B. Soenarto, Rekayasa Peresapan Buatan untuk Mengatasi Susutnya Peresapan Air Alami Akibat Konservasi Lahan Alami Menjadi Lahan Permukiman, Seminar Sehati "Air Tanah Cekungan Bandung”, Satgas Penelitian Sumberdaya Air ITB Bandung, II-11-II-58 (1995)

9. K. Iriani, A. Gunawan, B. Besperi, Perencanaan Sumur Resapan Air Hujan untuk Konservasi Air Tanah di Daerah Permukan (Studi Kasus di Perumahan RT II, III, dan IV Perumahan Lingkar Timur Bengkulu), Inersia, 5, 9-22 (2013)

10. A. Azis, Y. Hamzah, F. Zulviyah, Konservasi Airtanah Melalui Pembuatan Sumur Resapan Air Hujan di Keluarahan Maradekaya Kota Makassar, Intek, 3 (2), 87-90 (2016)

11. S. Sunjoto, Infiltration Well and Urban Drainage Concept, Conference on Future Groundwater Resources at Risk, IAHS Publ. no. 222, Helsinki, 527-532 (1994)

12. M. Sobolewski, Various Method of The Measurement of The Permeability Coefficient in Soils - Possibilities and Application, Electronic
Journal of Polish Agricultural Universities, 8, 2 (2005) 